\title{
EFEK SISA ASAM HUMAT DARI KOMPOS ALANG-ALANG DAN PENGELOLAAN AIR DALAM MENGURANGI KELARUTAN BESI (FE) PADA TANAH SAWAH BUKAAN BARU
}

\author{
Herviyanti, Gusnidar dan Rina Alfina \\ J urusan Tanah F akultas Pertanian U niversitas Andalas Padang
}

\begin{abstract}
The research about residue effect of humic acid from imperata compost and water management to decrease the dissolved of iron (fe) on recently used ricefield had been conducted from march till august 2007. The objective is to study residue effect of humic acidity aplication and water management to controlling $\mathrm{Fe}$ and to increase rice production on recently used ricefield. The experiment using design factorial $2 \times 4$ with three replication wich is place as the split plot. The major factor is water management consisted of two treatment, thos were continously flooded $\left(\mathrm{P}_{1}\right)$ and flooded and dried (intermittence) with two week interval $\left(\mathrm{P}_{2}\right)$. The minor factor are four level from residue effect of humic acid $(0,200,400,600 \mathrm{ppm})$. The result of this study can provided the information that residue effect of humic acid at $600 \mathrm{ppm}$ can reduce solubility of $\mathrm{Fe}^{2+}$ from 327,91 to 37,53 ppm for continously flooded and from 173,51 to $38,13 \mathrm{ppm}$ for intermitten flooded. And the yield of rice (dry weight of 1000 grain ad straw) increase as much as 4,9 and 5,38 g with residue effect of humic acid at $600 \mathrm{ppm}$ combination with intermittence flooded.
\end{abstract}

Key word : humic acid, iron, recently used ricefield, intermittence, flooded.

\section{PENDAHULUAN}

Dampak negatif dari alih fungsi lahan yang terjadi pada daerah sentra produksi beras mengakibatkan menurunnya produksi beras pada tahun 1986, sehingga Indonesia mulai mengimpor beras untuk mencukupi kebutuhan nasional (Noor, 1996). Alternatif impor ini cukup riskan terhadap sektor pertanian Indonesia dimasa yang akan datang.

Salah satu usaha untuk mengatasi terjadinya impor beras adalah melalui pencetakan sawah baru dengan memanfaatkan lahan-lahan marginal, baik lahan kering maupun lahan gambut, dan rawa. Dari ketiga lahan marginal tersebut, lahan kering marginal penyebarannya paling luas di Indonesia yaitu $\pm 50 \%$ (Noor, 1996). Jenis tanah yang mendominasi pada lahan ini adalah Ultisol dan Oxsisol atau disebut juga Podzolik Merah Kuning (PMK). Hampir setiap pulau di Indonesia terdapat lahan dengan jenis ini seperti di Kalimantan, Papua, Sumatera dan Sulawesi berturut-turut seluas \pm 30.01 juta Ha, 21.81 juta Ha, 20.05 juta Ha dan 14.68 juta Ha (Noor, 1996). Untuk Sumetera Barat, salah satu daerah yang dijadikan sasaran pencetakan sawah baru, adalah Kabupaten Dharmasraya , dimana sebagian besar jenis tanahnya adalah Ultisol dan Oksisol dengan luas lahan yang telah dibuka yaitu $950 \mathrm{Ha}$ (Rusman, 1990).

Sawah bukaan baru hampir selalu dihadapkan kepada permasalahan rendahnya produktifitas lahan diawal pemanfaatan. Kendala yang sering ditemui setelah tanah digenangi adalah keracunan besi (Fe) (Taher, 1990). Menurut Ponnamperuma (1978) konsentrasi $\mathrm{Fe}$ dapat larut bervariasi dari 0,1 ppm sebelum penggenangan, dan setelah penggenangan akan meningkat menjadi 600 ppm. Lebih lanjut Herviyanti, Prasetyo, Alif dan Tjandra (2005) menjelaskan bahwa, kandungan Fe-dd sebelum penggenangan pada tanah jenis Ultisol dari Sitiung mencapai 60,49 ppm dan setelah penggenangan selama 6 minggu kandungan Fe meningkat menjadi 1600 ppm.

Keracunan $\mathrm{Fe}$ menyebabkan pertumbuhan tanaman padi terhambat, kerdil dan pembentukan anakan terbatas akibat terbatasnya perkembangan akar, serta dapat memberikan hasil padi $\pm 52-75 \%$ lebih rendah dibandingkan tanaman sehat (Burbey, Hamzah, dan Zaini, 1990). Upaya yang 
dapat dilakukan dalam mengatasi keracunan Fe pada tanah sawah bukaan baru adalah melalui pemberian bahan organik dan pengelolaan air. Pengelolaan air dengan cara pengairan berselang (Intermitten) dapat mengatasi keracunan $\mathrm{Fe}$ terhadap padi. Herviyanti et. al. (2005) menjelaskan bahwa penggenangan dan pengeringan selama 2 minggu dapat mengurangi kandungan $\mathrm{Fe}$ sekitar 1250 ppm. Penurunan Fe ini terjadi karena ketika tanah digenangi, maka akan terjadi reduksi $\mathrm{Fe}^{+3}$ menjadi $\mathrm{Fe}^{+2}$ dimana $\mathrm{Fe}^{+2}$ ini akan tercuci saat dilakukan saat pengeringan serta terjadi proses oksidasi $\mathrm{Fe}^{2+}$ menjadi $\mathrm{Fe}^{3+}$ yang tidak larut.

Pemberian asam humat dalam mengatasi masalah keracunan $\mathrm{Fe}$ pada tanah sawah telah dilakukan dan ternyata dapat mengurangi kandungan Fe. Herviyanti et al (2005), menyatakan bahwa pemberian asam humat dari kompos alang-alang takaran 200 menjadi 600 ppm pada tanah sawah bukaan baru, dapat mengurangi kandungan $\mathrm{Fe}$ sebesar 643,95 ppm. Hal ini dikarenakan terjadi reaksi antara $\mathrm{Fe}^{2+}$ dengan gugus fungsional dari asam humat membentuk kompleks organo logam. Disamping itu, pemberian asam humat diasumsikan dapat bertahan lama di dalam tanah, sehingga dapat menimbulkan efek sisa yang bisa menurunkan kandungan $\mathrm{Fe}^{2+}$ dan meningkatkan produksi padi secara optimal.

Efek sisa yang ditimbulkan oleh asam humat akan terlihat setelah penanaman berikutnya. Berapa lama efek sisa asam humat mampu mengurangi $\mathrm{Fe}^{2+}$ belum diketahui, oleh karena itu perlu dilakukan penelitian lanjutan.

Penelitian ini bertujuan untuk mempelajari interaksi antara efek sisa asam humat dan pengelolaan air terhadap kandungan Fe tanah sawah bukaan baru dan serapan hara serta hasil tanaman padi.

\section{BAHAN DAN METODA}

Penelitian dilaksanakan di Laboratorium dan Rumah kaca Fakultas Pertanian Universitas Andalas dari bulan Maret sampai Agustus 2007. Tanah yang digunakan adalah tanah jenis Ultisol. Sebagai tanaman indikator digunakan padi varietas Cisokan. Untuk pemupukan digunakan Urea, SP-36, dan $\mathrm{KCl}$. Rancangan percobaan yang digunakan adalah Faktorial $2 \times 4$ dalam petak terbagi dengan 2 perlakuan pengelolaan air sebagai petak utama, 4 dosis asam humat sebagai anak petak dan 3 ulangan.

Petak utama adalah pengelolaan air, yang terdiri atas:

$\mathrm{P}_{1}$ : Penggenangan terus menerus

$\mathrm{P}_{2}$ : Penggenangan 2 minggu dan pengeringan 2 minggu

Anak petak terdiri atas efek sisa 4 dosis asam humat yang diberikan pada penanaman pertama:

$\mathrm{A}_{0}: 0 \mathrm{ppm}$ setara dengan $0 \mathrm{~kg}$ asam humat/ha

$\mathrm{A}_{1}: 200 \mathrm{ppm}$ setara dengan $400 \mathrm{~kg}$ asam humat/ha

A2 : $400 \mathrm{ppm}$ setara dengan $800 \mathrm{~kg}$ asam humat/ha

A3 : 600 ppm setara dengan $1200 \mathrm{~kg}$ asam humat/ha

Percobaan dilakukan dengan menggunakan ember plastik berdiameter 30 $\mathrm{cm}$. Ember yang telah diisi tanah sebanyak $10 \mathrm{~kg}$ setara kering mutlak pada penanaman pertama, kemudian digenangi dengan tinggi $\pm 5 \mathrm{~cm}$ selama 2 minggu. Setelah itu dilakukan pengeringan untuk penggenangan selang seling (intermitten). Selanjutnya diambil sampel tanah untuk pengamatan $\mathrm{P}$ dan $\mathrm{Fe}^{2+}$ setelah perlakuan. Pengamatan $\mathrm{Fe}^{2+}$, selanjutnya dilakukan pada minggu ke 4 dan 8 setelah penggenangan.

Setelah dilakukan pemupukan dasar $\mathrm{N}, \mathrm{P}, \mathrm{K}$ dengan takaran $200 \mathrm{~kg} \mathrm{ha}^{-1}$ Urea (setara 1,25 $\mathrm{g} \mathrm{pot}^{-1}$ ), $150 \mathrm{SP}-36$ (setara $\left.0,9375 \mathrm{~g} \mathrm{pot}^{-1}\right)$ dan $100 \mathrm{~kg} \mathrm{ha}^{-1} \mathrm{KCl}(0,625$ g pot $^{-1}$ ) dengan asumsi jarak tanam $25 \mathrm{~cm} \mathrm{x}$ $25 \mathrm{~cm}$ dan ditanami padi varietas Cisokan.

Tiap pot ditanami dengan 3 bibit padi berumur \pm 21 hari. Pemeliharaan tanaman dilakukan dengan menjaga agar tanah selalu tergenang air untuk penggenangan terus menerus dan lembab untuk penggenangan selang-seling. Saat terjadi serangan hama maka tanaman disemprot dengan insektisida Dharmabas konsentrasi 5 - $10 \mathrm{cc} \mathrm{L-1.}$ 
Pengambilan sampel daun tanaman untuk menentukan kadar hara tanaman $(\mathrm{P}$ dan $\mathrm{Fe}$ ) dilakukan pada saat pertumbuhan vegetatif maksimum (umur 60 hari), kemudian dimasukkan ke dalam oven pada suhu $60{ }^{\circ} \mathrm{C}$ selama $\pm 2 \times 24$ jam (sampai bobotnya tetap), dan dihaluskan dengan grinder. Pada saat yang sama diamati jumlah anakan dan tinggi tanaman.

Panen dilakukan pada saat tanaman berumur 115 hari. Kemudian dilakukan penimbangan bobot gabah kering dan bobot jerami kering.

\section{HASIL DAN PEMBAHASAN}

a. Kadar $\mathrm{Fe}^{+2}$ dalam larutan tanah

selama 8 minggu penggenangan

Interaksi antara efek sisa asam humat dan pengelolaan air terhadap kadar
$\mathrm{Fe}+2$ tanah sawah, dapat dilihat pada Gambar 1. Dari Gambar 1 terlihat bahwa kadar $\mathrm{Fe}^{+2}$ dalam larutan tanah untuk semua perlakuan mengalami peningkatan. Peningkatan kadar $\mathrm{Fe}^{+2}$ terus terjadi hingga minggu ke 8 penggenangan. Dari kedua gambar di atas terlihat bahwa kadar $\mathrm{Fe}^{+2}$ tertinggi hingga minggu ke 8 penggenangan terdapat pada tanah tanpa efek sisa asam humat, yaitu : 327,91 ppm untuk tanah yang digenangi terus-menerus dan $173,51 \mathrm{ppm}$ untuk tanah yang digenangi selang-seling. Secara umum kadar $\mathrm{Fe}^{+2}$ tanah pada masingmasing efek sisa asam humat dengan takaran 200 sampai 600 ppm juga mengalami peningkatan, namun peningkatannya jauh lebih rendah dibanding tanpa asam humat. Hingga minggu ke 8 penggenangan, peningkatan kadar $\mathrm{Fe}^{+2}$ untuk
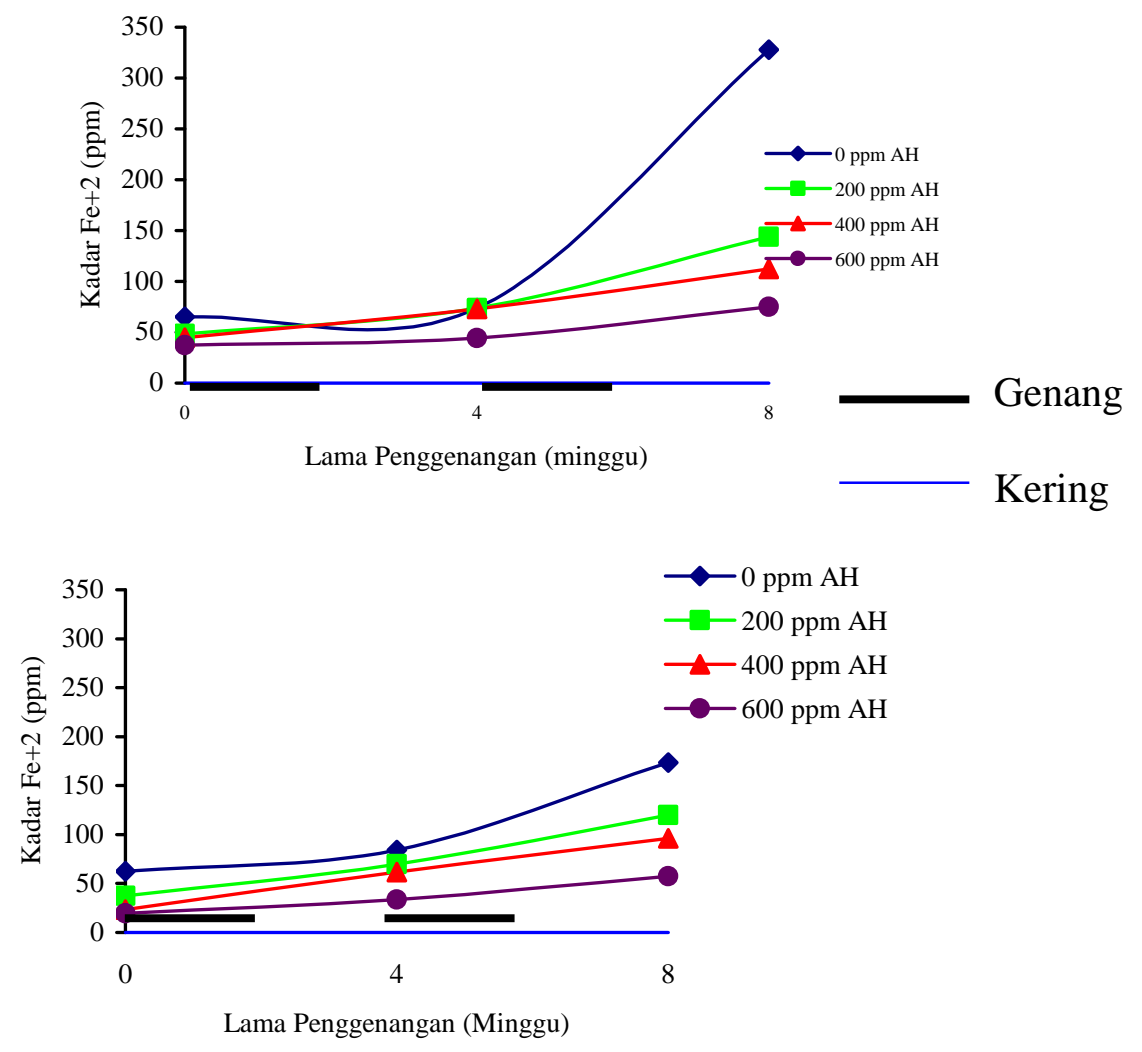

Gambar 1. Hubungan kadar $\mathrm{Fe}^{+2}$ tanah sawah dengan lama penggenangan akibat efek sisa asam humat dari kompos alang-alang dengan penggenangan terus menerus (atas) dan selang-seling (bawah). 
tanah yang digenangi terus-menerus akibat efek sisa asam humat berturut-turut: 95,46; 67,48; dan 37,53 ppm; sedangkan untuk tanah yang digenangi selang-seling masingmasing sebesar 82,54; 73,14 dan 38,13 ppm. Peningkatan kadar $\mathrm{Fe}$ yang semakin menurun dengan bertambahnya takaran asam humat ini diasumsikan karena semakin tinggi takaran asam humat, maka sisa asam humat yang ada di dalam tanah juga semakin meningkat. Peningkatan kandungan asam humat di dalam tanah akan memperbanyak pengikatan $\mathrm{Fe}$ dalam bentuk reaksi khelat dan kompleks, sehingga kadar $\mathrm{Fe}$ dalam larutan tanah akan semakin menurun.

Kadar $\mathrm{Fe}^{+2}$ pada tanah dengan penggenangan selang-seling lebih rendah dari kadar $\mathrm{Fe}^{+2}$ tanah yang digenangi terusmenerus. Hal ini dikarenakan pada penggenangan selang-seling tanah tidak mengalami kondisi reduksi secara terusmenerus, sehingga reduksi $\mathrm{Fe}^{+3}$ menjadi $\mathrm{Fe}^{+2}$ tidak berlangsung secara kontinyu, dimana kecepatan reduksinya juga lebih lambat (Eh berkisar antara 115.43- $146.00 \mathrm{mV}$ ). Selain itu, rendahnya kadar $\mathrm{Fe}^{+2}$ pada penggenangan selang-seling ini disebabkan oleh sebagian $\mathrm{Fe}$ yang larut saat tanah digenangi ikut tercuci pada waktu pengeringan tanah.
Kadar $\mathrm{Fe}^{+2}$ yang berkisar antara 57.58 - $327.91 \mathrm{ppm}$ pada penanaman kedua ini masih berada pada konsentrasi yang meracun bagi tanaman. Tanaka (1966, dalam Herviyanti 2007) mengemukakan bahwa Fe larutan tanah yang meracun bagi tanaman berkisar antara $10-1000$ ppm. Walaupun demikian, kadar $\mathrm{Fe}^{+2}$ pada penanaman ke dua ini jauh lebih rendah dari pada kadar $\mathrm{Fe}+2$ pada penanaman pertama. Kadar $\mathrm{Fe}^{+2}$ pada penanaman pertama mencapai $900-1000$ ppm, dengan kemampuan asam humat dalam mengurangi keracunan $\mathrm{Fe}$ mencapai $180 \mathrm{ppm}$ (Herviyanti, 2007). Pada penanaman ke dua kadar $\mathrm{Fe}^{+2}$ dapat ditekan hingga 57.58 114,17 ppm. Hal ini menunjukkan bahwa efek sisa asam humat masih mampu mengurangi kadar $\mathrm{Fe}^{+2}$ tanah hinggga penanaman ke dua, namun kemampuannya mengalami penurunan.

b. Kandungan P-tersedia tanah sawah bukaan baru selama 8 minggu penggenangan

Pengaruh pengelolaan air dan efek sisa asam humat terhadap ketersediaan $\mathrm{P}$ tanah disajikan pada Gambar 2.

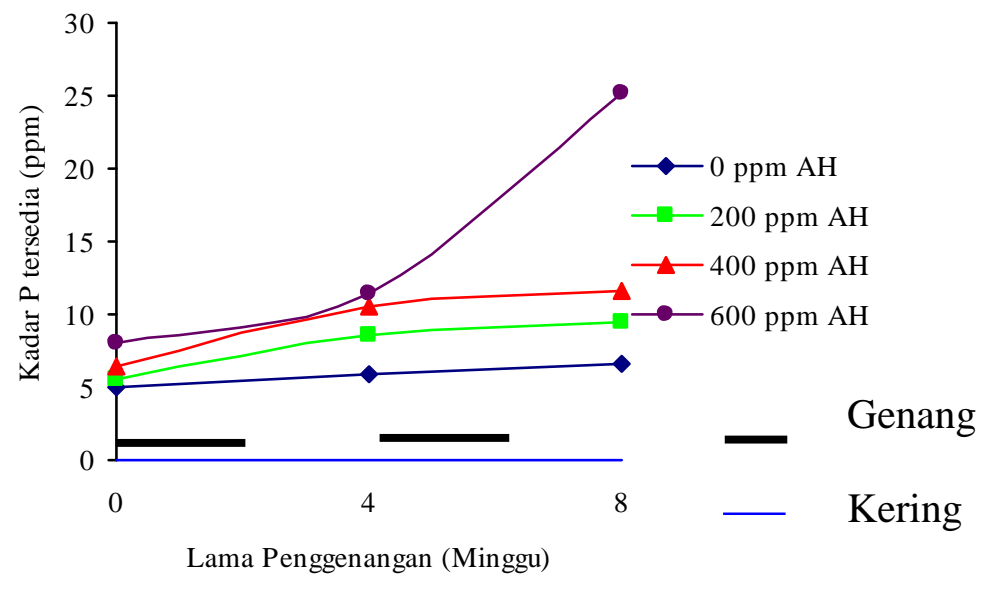




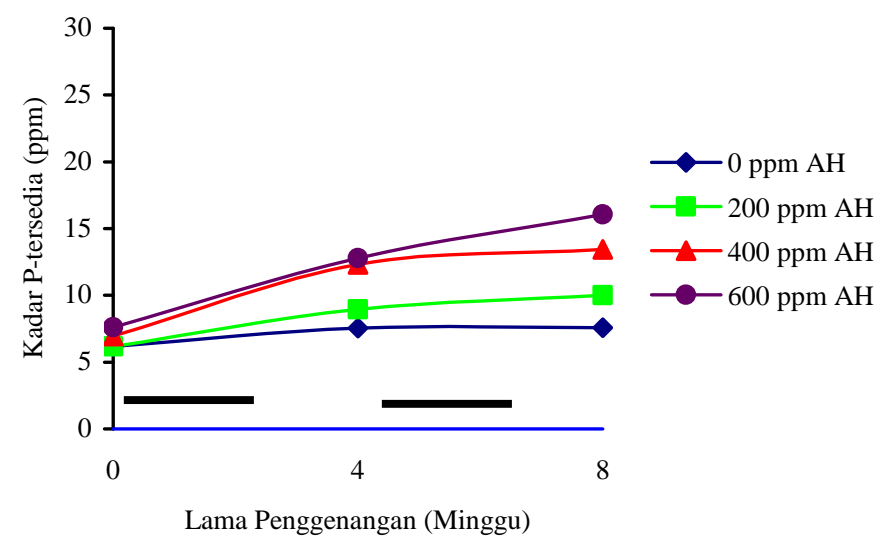

Gambar 2. Hubungan lama penggenangan dengan Kadar P-tersedia tanah sawah efek sisa asam humat dari kompos alang-alang dengan penggenangan terus menerus (atas) dan selang-seling (bawah).

Secara umum pada Gambar 2 terlihat bahwa ketersediaan $\mathrm{P}$ tanah semakin meningkat hinggga minggu ke 8 penggenangan. Kenaikan P ini berkisar antara $1.58-17.19$ ppm untuk tanah yang digenangi terusmenerus dan 3.86- $8.47 \mathrm{ppm}$ untuk tanah yang digenangi selang-seling. Kenaikan kandungan P-tersedia ini lebih besar dari kenaikan $\mathrm{P}$ tersedia pada tanah tanpa efek sisa asam humat. Tanah yang digenangi terus-menerus tanpa efek sisa asam humat hanya mengalami kenaikan $\mathrm{P}$ sebesar 1.58 ppm dan untuk tanah yang digenangi selang-seling tanpa efek sisa asam humat mengalami kenaikan $\mathrm{P}$ sebesar $1.41 \mathrm{ppm}$. Rendahnya kenaikan $\mathrm{P}$ pada tanah tanpa efek sisa asam humat disebabkan oleh tidak adanya kandungan asam humat yang dapat melepaskan ikatan $\mathrm{P}$ dari $\mathrm{Fe}$ tanah. $\mathrm{P}$ yang tersedia pada tanah tanpa asam humat hanya berasal dari pengaruh penggenangan saja.

Terjadinya peningkatan kadar Ptersedia ini disebabkan oleh semakin tinggi kandungan asam humat di dalam tanah, maka kemampuannya dalam melepaskan $\mathrm{P}$ dari $\mathrm{Fe}$ semakin meningkat. Semakin menurunnya jumlah peningkatan kelarutan kadar $\mathrm{Fe}$ tanah, maka kandungan P-terdia tanah akan semakin besar.

Peningkatan kandungan P-tersedia terbesar ditemukan pada tanah dengan efek sisa asam humat $600 \mathrm{ppm}$, yaitu $17.19 \mathrm{ppm}$ untuk tanah yang digenangi terus-menerus dan $8.47 \mathrm{ppm}$ untuk tanah yang digenagi selang-seling. Hal ini dikarenakan pada takaran tersebut diasumsikan kandungan asam humat di dalam tanah lebih besar. Semakin besar efek sisa asam humat dalam tanah, maka gugus fenolik dan hidroksil yang dapat mengikat Fe juga lebih besar, sehingga $\mathrm{P}$ yang terlepas ke larutan tanah menjadi lebih banyak. Tan (1998) mengemukakan bahwa asam humat sangat efektif dalam mengikat hara-hara mikro, seperti $\mathrm{Fe}, \mathrm{Cu}, \mathrm{Zn}$, dan $\mathrm{Mn}$. Dalam tanah masam seperti Ultisol hara mikro ini terdapat dalam jumlah besar dan menyebabkan masalah keracunan pada tanaman. Dengan memberikan asam humat ke dalam tanah, sebagian besar hara mikro yang ada akan diikat melalui reaksi khelat dan kompleks.

Kenaikan kandungan P-tersedia tanah yang digenangi selang-seling lebih rendah dari kenaikan P-tersedia tanah yang digenangi terus-menerus. Hingga minggu ke 8 penggenangan, jumlah kenaikan p-tersedia tanah yang digenangi selang-seling yaitu 20.25 ppm, sedangkan untuk tanah yang digenangi terus-menerus mencapai 27.72 ppm. Hal ini dikarenakan pada tanah yang digenangi selang-seling sebagian $\mathrm{P}$ yang telah terlepas ke dalam larutan tanah diasumsikan ikut tercuci saat tanah dikeringkan. P-tersedia yang lebih besar pada penggenangan terus-menerus 
disebabkan oleh semakin lama tanah digenangi, maka $\mathrm{P}$ yang diikat oleh $\mathrm{Fe}(\mathrm{III})$ menjadi terlepas seiring dengan terjadinya reduksi Fe(III) menjadi Fe(II). Willet (1991, dalam Badan Penelitian dan Pengembangan Pertanian Departemen Pertanian, 2004) melaporkan bahwa reduksi ferioksida merupakan sumber yang dominan bagi pelepasan $\mathrm{P}$ selama penggenangan, walaupun $\mathrm{P}$ yang dilepaskan akan dijerap kembali.

Kandungan P-tersedia pada penanaman ke dua ini lebih tinggi dari kandungan P-tersedia tanah pada penanaman I. P-tersedia pada penanaman ke dua hingga mingggu ke 8 penggenangan berkisar antara 6.61 - 25.14 ppm (Gambar 7. dan Gambar 8.) untuk semua perlakuan, sedangkan Ptersedia pada penanaman ke dua hanya berkisar antara $5.16-8.44 \mathrm{ppm}$. Hal ini dikarenakan kadar Fe tanah yang dapat mengikat $\mathrm{P}$ pada penanaman ke dua ini juga lebih rendah, yaitu berkisar antara 57.58 $327.91 \mathrm{ppm}$. Selain itu, peningkatan takaran pemupukan $\mathrm{P}$ pada penanaman kedua dari $150 \mathrm{~kg} / \mathrm{Ha}$ menjadi $300 \mathrm{~kg} / \mathrm{Ha}$ menyebabkan kandungan P-tersedia tanah pada penanaman ke dua ini meningkat.

\section{c. Jumlah anakan produktif (batang)}

Pengaruh utama pengelolaan air berbeda nyata terhadap jumlah anakan produktif, sedangkan pengaruh utama efek sisa asam humat tidak nyata dan tidak terjadi interaksi antara kedua faktor terhadap jumlah anakan produktif. Hal ini terlihat jelas pada Tabel 1 .

Dari Tabel 1 diatas terlihat bahwa jumlah anakan produktif tanaman padi pada penggenangan selang-seling lebih banyak bila dibandingkan dengan pengenangan terus-menerus. Peningkatan jumlah anakan produktif pada penggenangan selang-seling untuk semua sisa asam humat mencapai \pm 5 anakan dibanding penggenangan terus menerus. Hal ini menunjukkan bahwa penggenangan selang seling dapat memperbaiki pertumbuhan tanaman padi.

Peningkatan jumlah anakan produktif yang lebih banyak pada penggenangan selang-seling ini terjadi sebagai akibat berkurangnya keracunan $\mathrm{Fe}^{+2}$ terhadap tanaman. Dari Gambar 1 terlihat bahwa kelarutan $\mathrm{Fe}$ pada penggenangan selang-selimg lebih rendah bila dibandingkan dengan kelarutan $\mathrm{Fe}$ pada penggenangan terus-menerus ppm (Gambar 3.). Kelarutan $\mathrm{Fe}$ yang tinggi akan menghambat pertumbuhan akar tanaman, sehingga pembentukan anakan akan menjadi terhambat. Yusuf et al (1990) mengemukakan bahwa kelarutan $\mathrm{Fe}$ yang tinggi akan mengendap di permukaan akar tanaman sehingga dapat menghambat perkembangan akar. Semakin menurunnya kelarutan Fe pada tanah, maka keracunan $\mathrm{Fe}$ terhadap tanaman akan semakin menurun, sehingga pertumbuhan tanaman akan menjadi lebih baik.

Peningkatan jumlah anakan produktif pada penanaman kedua ini relatif

Tabel 1. Efek sisa asam humat terhadap jumlah anakan produktif tanaman padi umur 60 hari pada tanah sawah bukaan baru jenis Ultisol yang digenangi selang-seling dan terus menerus penanaman ke dua.

\begin{tabular}{lccccc}
\hline Penggenangan & \multicolumn{4}{c}{ Takaran Asam Humat (ppm) } & Rata-rata \\
\cline { 2 - 5 } & 0 & 200 & 400 & 600 & \\
\hline Terus-menerus & 7 & 7,33 & 8 & 8,33 & $7,67 \mathrm{~b}$ \\
Selang-seling & 10,33 & 12 & 12,33 & 15 & $12,42 \mathrm{a}$ \\
\hline Rata-rata & 8,67 & 9,67 & 10,17 & 11,67 & -
\end{tabular}

Angka-angka yang diikuti oleh huruf kecil yang sama pada kolom yang sama berbeda tidak nyata menurut DNMRT 5\% 
sama dengan peningkatan jumlah anakan produktif pada penanamn pertama, yaitu berkisar 5 anakan. Hal ini dikarenakan tanaman mengalami keracunan $\mathrm{Fe}^{+2}$ baik pada penanaman pertama, maupun pada penanaman kedua. Keracunan $\mathrm{Fe}^{+2}$ pada penanaman kedua ini sudah mulai terlihat saat tanaman berumur 5 minggu setelah tanam. Keracunan ini terlihat dari warna daun tanaman yang berwarna bercak kecoklat-coklatan.

\section{d. Kadar Fe tanaman (ppm)}

Pengaruh utama sisa asam humat berbeda nyata terhadap kadar $\mathrm{Fe}$ tanaman, sedangkan pengelolaan air dan interaksi antara efek sisa asam humat dengan pengelolaan air tidak berpengaruh terhadap kadar Fe tanaman seperti terlihat pada Tabel 2. Secara umum kadar Fe tanaman menurun dengan adanya peningkatan kandungan sisa asam humat. Kadar $\mathrm{Fe}$ tanaman pada sisa asam humat $400 \mathrm{ppm}$ menurun sebesar $17,33 \mathrm{ppm}$, sedangkan pada sisa asam humat $600 \mathrm{ppm}$ menurun sebesar 44,95 ppm. Hal ini membuktikan bahwa semakin tinggi takaran asam humat yang diberikan, maka diasumsikan sisa asam humat yang ada di dalam tanah semakin meningkat, sedangkan jumlah $\mathrm{Fe}$ yang larut semakin berkurang (Gambar 1). Dengan berkurangnya kelarutan Fe tanah, maka jumlah Fe yang diserap oleh tanaman akan semakin menurun.

Secara umum kadar $\mathrm{Fe}$ tanaman pada semua perlakuan masih meracuni tanaman. Hal ini terlihat dari gejala keracunan $\mathrm{Fe}$ pada daun tanaman yang berwarna coklat kemerahan. Gejala ini mulai terlihat pada saat tanaman berumur 5 minggu setelah tanam. Marschner (1995) mengemukakan bahwa akibat dari keracunan $\mathrm{Fe}$ pada tanaman padi adalah produksi dari radikal oksigen yang berlebihan, melebihi kapasitas tanaman untuk mengontrol radikal-radikal ini. Selanjutnya dijelaskan bahwa radikal hidroksil yang terbentuk pada kadar $\mathrm{Fe}$ yang tinggi akan menyebabkan auto katalis dari lemak dalam membran sel dan degradasi dari protein yang diperlihatkan dengan adanya bronzing pada daun tanaman.

Kadar Fe tanaman pada penanaman ke dua ini lebih rendah dari kadar $\mathrm{Fe}$ tanaman pada penanaman pertama. Pada penanaman pertama kadar $\mathrm{Fe}$ tanaman berkisar antara 78.47 - 249.20 ppm, sedangkan pada penanaman ke dua hanya berkisar antara $50.38-105.341$ ppm. Hal ini dikarenakan kelarutan $\mathrm{Fe}$ pada penanaman ke dua juga lebih rendah, yaitu 57.53 327.91 ppm, sedangkan kelarutan Fe pada penanaman pertama mencapai $900-1000$ ppm (Herviyanti, 2007). Semakin rendahnya kelarutan $\mathrm{Fe}$ tanah, maka jumlah $\mathrm{Fe}$ yang diserap oleh tanaman juga semakin menurun. Hal ini membuktikan bahwa hingga penanaman ke dua efek sisa asam humat ternyata masih mampu mengurangi kadar Fe tanaman yang terlihat dari semakin menurunnya kadar Fe tanaman.

Tabel 2. Efek sisa asam humat terhadap kadar Fe tanaman umur 60 hari pada tanah sawah bukaan baru jenis tanah Ultisol dengan pengelolaan air dan sisa asam humat.

\begin{tabular}{lccccc}
\hline \multirow{2}{*}{ Penggenangan } & \multicolumn{4}{c}{ Takaran Asam Humat (ppm) } & \multirow{2}{*}{$\begin{array}{c}\text { Rata- } \\
\text { rata }\end{array}$} \\
\cline { 2 - 5 } & 0 & 200 & 400 & 600 & \\
\hline Terus-menerus & 114,38 & 114,32 & 94,06 & 50,92 & 93,42 \\
Selang-seling & 96,30 & 86,51 & 81,98 & 49,85 & 78,66 \\
\hline Rata-rata & $105,34 \mathrm{~A}$ & $100,41 \mathrm{AB}$ & $88,01 \mathrm{~B}$ & $50,39 \mathrm{C}$ & \\
\hline
\end{tabular}

Angka-angka yang diikuti oleh huruf besar yang sama pada baris yang sama berbeda tidak nyata menurut DNMRT 5\%. 
e. Berat 1000 butir gabah dan berat kering jerami(g)

Tabel 3. Efek sisa asam humat terhadap berat 1000 butir gabah dengan penggenangan selangseling dan terus-menerus.

\begin{tabular}{cccccc}
\hline \multirow{2}{*}{ Penggenangan } & \multicolumn{4}{c}{ Takaran Asam Humat (ppm) } & \multirow{2}{*}{ Rata-rata } \\
\cline { 2 - 5 } & 0 & 200 & 400 & 600 & \\
\hline Terus-menerus & 12,41 & 13,11 & 14,55 & 16,01 & $14,02 \mathrm{~b}$ \\
Selang-seling & 16,64 & 18,49 & 19,94 & 20,63 & $18,92 \mathrm{a}$ \\
\hline Rata-rata & $14,53 \mathrm{C}$ & $15,79 \mathrm{C}$ & $17,24 \mathrm{AB}$ & $18,32 \mathrm{~A}$ & \\
\hline Rny
\end{tabular}

Angka-angka yang diikuti oleh huruf besar yang sama pada baris yang sama, dan angka-angka yang diikuti oleh huruf kecil yang sama pada kolom yang sama berbeda tidak nyata menurut DNMRT 5\%.

Tabel 4. Efek sisa asam humat terhadap berat kering jerami yang ditanam pada tanah sawah bukaan baru jenis tanah Ultisol dengan pengelolaan air dan dengan berbagai sisa asam humat pada berbagai takaran.

\begin{tabular}{cccccc}
\hline \multirow{2}{*}{ Penggenangan } & \multicolumn{4}{c}{ Takaran Asam Humat (ppm) } & \multirow{2}{*}{ Rata-rata } \\
\cline { 2 - 5 } & 0 & 200 & 400 & 600 & \\
\hline Terus-menerus & 8,51 & 11,13 & 11,69 & 12,09 & $10,85 \mathrm{~b}$ \\
Selang-seling & 12,58 & 17,04 & 17,83 & 18,29 & $16,43 \mathrm{a}$ \\
\hline Rata-rata & 10,54 & 14,09 & 14,76 & 15,19 & \\
\hline
\end{tabular}

Angka-angka yang diikuti oleh huruf kecil yang sama pada kolom yang sama berbeda tidak nyata menurut DNMRT 5\%.

Pengaruh utama sisa asam humat dan pengelolaan air berbeda nyata terhadap berat 1000 butir gabah dan tidak ditemukan interaksi antar perlakuan (Tabel 3). Sedangkan pengaruh efek sisa asam humat tidak nyata terhadap bobot kering jerami padi (Tabel 4).

Dari Tabel 3 dan 4 terlihat bahwa berat 1000 butir gabah dan berat kering jerami pada penggenangan selang-seling lebih berat 4,90 dan 5,38 g dibanding penggenangan terus-menerus. $\mathrm{Hal}$ ini membuktikan bahwa dengan penggenangan selang-seling tanaman dapat tumbuh lebih baik, dimana keracunan $\mathrm{Fe}$ terhadap tanaman dapat berkurang. Kandungan $\mathrm{Fe}^{+2}$ tanah yang lebih rendah $(19,45-173,51$ ppm) pada penggenangan selang-seling dapat meningkatkan ketersediaan hara bagi tanaman terutama kandungan hara $\mathrm{P}$ yang sangat penting bagi pembentukan malai.

Efek sisa asam humat takaran 400 ppm dapat meningkatkan berat gabah sebesar 2,71 g dibanding tanpa asam humat, baik pada penggenangan terus menerus mapun pada penggenangan selang seling. Berat gabah dan jerami tertinggi terdapat pada perlakuan sisa asam humat $600 \mathrm{ppm}$ (1200 kg/ha) yang dikombinasikan dengan penggenangan selang-seling masing-masing sebesar 8,22 dan 9,78 g lebih berat dibanding penggenangan terus menerus tanpa efek sisa asam humat. Bila dibandingkan dengan penanaman pertama, berat 1000 butir pada penanaman kedua relatif sama. Hal ini dikarenakan tanaman masih keracunan $\mathrm{Fe}^{+2}$ sehingga tanaman belum dapat tumbuh dengan baik.

\section{KESIMPULAN}

Secara umum, semakin meningkat sisa asam humat di dalam tanah, maka peningkatan kelarutan $\mathrm{Fe}$ tanah semakin menurun. Peningkatan kelarutan Fe terendah ditemukan pada takaran asam humat 600 ppm, yaitu 37.53 ppm untuk tanah yang 
digenangi terus-menerus dan $38.13 \mathrm{ppm}$ untuk tanah yang digenangi selang-seling.

Produksi tanaman padi juga meningkat akibat efek sisa Asam humat. Semakin tinggi sisa Asam Humat di dalam tanah semakin tinggi pula berat 1000 butir gabah dan jerami yang diperoleh. Berat 1000 butir gabah tertinggi ditemukan pada perlakuan efek sisa Asam Humat pada takaran $600 \mathrm{ppm}$ dikombinasikan dengan penggenangan selang- seling yaitu masingmasing sebesar 8,22 dan 9,78 g lebih berat dibanding penggenangan terus menerus tanpa efek sisa asam humat

\section{DAFTAR PUSTAKA}

Agus, F., A. Hadimihrdja, S. Hardjowigeno, A. M. Fagi, dan W. Hartatik. 2004. Tanah Sawah dan Teknologi Pengelolaannya. Pusat Penelitian dan Pengembangan Tanah dan Agroklimat. Badan Penelitian Tanah. Bogor. 328 hal.

Ahmad, F. 1990. Ameliorasi sawah bukaan baru dengan pupuk alam organic Dalam Prosiding Pengelolaan Sawah Bukaan Baru Menunjang Swasembada Pangan dan Program Transimigrasi di Padang Fakultas Pertanian Universitas Ekasakti Padang dan Balitan Sukarami Solok Halaman 193-198.

Burbey, Z. Hamzah dan Z. Zaini. 1990. Pengendalian keracunan besi di lahan masam. Dalam Prosiding Pengelolaan Sawah Bukaan Baru Menunjang Swasembada Pangan dan Program Transmigrasi di Padang. Fakultas Pertanian Universitas Ekasakti Padang dan Balitan Sukarami Solok. Halaman 367-385.

Gaspersz, V. 1995. Teknik Analisis dalam Penelitian Percobaan. Tarsito. Bandung. Halaman 396-449.

Herviyanti., T.B. Prasetyo, A. Alif, M.A. Tjandra. 2005. Upaya pengendalian keracunan besi $(\mathrm{Fe})$ dengan asam humat dan pengelolaan air untuk meningkatkan produktifitas tanah sawah bukaan baru. Laporan Penelitian Hibah Bersaing XIII-I Perguruan Tinggi. Universitas Andalas. Padang. 47 halaman.

Kyuma, K. 2004. Paddy Soil Science. Kyoto University Press, Japan and Trans Pacific Press. Australia.

Noor, M. 1996. Padi Lahan Marginal. Penebar Swasembada. Jakarta. 213 halaman.

Ponnamperuma, F.N. 1978. Electrochemical in sub merged soils and the growth of rice. In Soils and Rice. The International Rice Research Institute. Los Banos, Laguna Philipines. Halaman 421-437.

Ryan, J., G. Estefan and A. Rashid. 1999. Soil and Plant Analysis Laboratory Manual. $2^{\text {nd }}$ Edition. International Center for Agricultural Research in Dry Area (ICARDA) and National Agricultural Research Center, Islamabad, Pakistan. (NARS). pp $139-142$.

Rusman, B. 1990. Prospek pengembangan sawah bukaan baru pada tanah podsolik merah kuning. Dalam Prosiding : Pengelolaan sawah bukaan baru menunjang swasembada pangan dan program transmigrasi. Universitas Ekasakti dan BPTP Sukarami. Halaman 309-315.

Sanchez, P. 1993. Properties and Management of Soils in The Tropics, $1^{\text {st }}$ edition. Terjemahan dari Sifat dan Ciri Pengelolaan Tanah Tropika. Jilid 2 oleh Hamzah. A. Penerbit Institut Teknologi Bandung (ITB). Bandung. 273 halaman.

Taher, A. dan H. Abbas. 1990. Pengelolaan sawah bukaan baru menunjang pelestarian swasembada pangan dan program transmigrasi. Dalam prosiding : Pengelolaan sawah 
bukaan baru menunjang swasembada pangan dan program transmigrasi. Universitas Ekasakti dan BPTP Sukarami. Halaman 19 29.

Tan, K. H. 1998. Principles of Soil Chemistry. Third Edition Resived and Expanded Marcel Dekker, Inc. New York. 521 pp.

Yusuf, A, S. Djakamihardja., G. Satari., dan S.D. Sutami. 1990. Pengaruh $\mathrm{pH}$ dan Eh tanah terhadap kelarutan $\mathrm{Fe}, \mathrm{Al}$ dan $\mathrm{Mn}$ pada lahan sawah bukaan baru jenis Oxisol, Sitiung. Dalam Prosiding Pengelolaan Sawah Bukaan Baru Menunjang Swasembada Pangan dan Program Transmigrasi di Padang. Fakultas Pertanian. Universitas Ekasakti Padang dan Balitan Sukarami Solok. Halaman 237-263. 